\title{
ANALISIS EFEKTIVITAS PELAKSANAAN PEMUNGUTAN RETRIBUSI PENGUJIAN KENDARAAN BERMOTOR DI KOTA DENPASAR
}

\author{
I Made Endra Lesmana Putra \\ Universitas Hindu Indonesia, email: endralesmanaputra05@gmail.com
}

\begin{abstract}
Regional Regulation number 20 of 2011 concerning vehicle levies requires every vehicle operating in general to be roadworthy in order to provide a sense of security and comfort for the community. This levy is borne by the community because in the current era of regional autonomy, the regions are given greater authority to regulate and manage their own households as stipulated in Law No.23 of 2014 concerning Regional Government

The purpose of this study was to test the effectiveness of collecting motor vehicle test fees in the city of Denpasar from 2015-2018. The results of the study show that from 2015 to 2018 the realization of levies collection of vehicle testing always exceeds the budget target with a percentage above $100 \%$ which is very effective even though the achievement is still fluctuating up and down because the number of vehicles decreases and regulations change, but on average collection of motorized vehicle testing fees still shows very effective.
\end{abstract}

\section{Key Word: Efektivitas, Regulasi, Retribusi, Kendaraan}

\section{PENDAHULUAN}

Pertumbuhan penduduk yang begitu tinggi berdampak pada bertambahnya jumlah kendaraan yang ada,hal ini berdampak pada terjadinya kemacetan hampir di setiap tempat di wilayah Kota Denpasar, hal ini menjadi perhatian bagi pemerintah daerah khusunya kota Denpasar dalam mengenakan tarif retribusi untuk setiap kendaraan baru yang masuk ke wilayah kota Denpasar. Peraturan Daerah nomor 20 tahun 2011 tentang Retribusi kendaraan mewajibkan setiap kendaraan yang beroperasi secara umum agar laik jalan guna memberikan rasa aman dan nyaman bagi masyarakat. Retribusi ini dibebankan kepada masyarakat karena dalam era otonomi daerah sekarang ini, daerah diberikan kewenangan yang lebih besar untuk mengatur dan mengurus rumah tangganya sendiri yang diatur dalam UU No.23 Tahun 2014 tentang Pemerintah daerah, Tujuannya antara lain adalah untuk 
lebih mendekatkan pelayanan pemerintah kepada masyarakat, memudahkan masyarakat untuk memantau dan mengontrol penggunaan dana yang bersumber dari Anggaran Pendapatan dan Belanja Daerah (APBD), selain untuk menciptakan persaingan yang sehat antar daerah dan juga mendorong timbulnya sebuah inovasi bagi daerah tersebut. Sejalan dengan kewenangan tersebut, Pemerintah Daerah diharapkan lebih mampu menggali sumber-sumber keuangan khususnya untuk memenuhi kebutuhan pembiayaan pemerintahan dan pembangunan di daerahnya melalui Pendapatan Asli Daerah (PAD). Tuntutan peningkatan PAD semakin besar seiring dengan semakin banyaknya kewenangan pemerintahan yang dilimpahkan kepada daerah disertai pengalihan personil, peralatan, pembiayaan dan dokumentasi (P3D) ke daerah dalam jumlah besar. Sementara, sejauh ini dana perimbangan yang merupakan transfer keuangan oleh pusat kepada daerah dalam rangka mendukung pelaksanaan otonomi daerah, meskipun jumlahnya relatif memadai yakni sekurang- kurangnya sebesar 25 persen dari Penerimaan Dalam Negeri dalam APBN, namun daerah dalam hal ini harus lebih kreatif dalam meningkatkan PADnya untuk meningkatkan akuntabilitas dan keleluasaan dalam pembelanjaan APBD-nya.

Sumber-sumber penerimaan daerah yang potensial harus digali secara maksimal, namun tentu saja di dalam koridor peraturan perundang- undangan yang berlaku, termasuk diantaranya adalah pajak daerah dan retribusi daerah yang memang telah sejak lama menjadi unsur PAD yang utama.Salah satunya dari penerimaan sektor retribusi daerah yang diharapkan dapat mendukung sumber pembiayaan daerah dalam menyelenggarakan pembangunan daerah, sehingga akan meningkatkan dan memeratakan perekonomian serta kesejahteraan masyarakat di daerahnya. Fenomena yang terjadi di Wilayah Kota Denpasar adalah terkait pemungutan retribusi wajib pengujian kendaraan bermotor, target PAD yang ditetapkan selama 4 tahun terakhir mengalami penurunan setiap tahunnya dari tahun 2015 
sampai 2018 meskipun realisasi selalu tercapai bahkan melebihi dari jumlah target anggaran PAD. Berikut tabel Target dan Realisasi Retribusi Pengujian Kendaraan Bermotor di Kota Denpasar.

Tabel 1.1

Target dan Realisasi Retribusi

Pengujian Kendaraan Bermotor di Kota Denpasar tahun 2015 s.d. 2018

\section{Tahun \\ Jumlah \\ Target \\ Realisasi \\ Persentase}

Kendaraan

\begin{tabular}{lllll}
\hline 2015 & 65.299 & 4.060 .000 .000 & 4.536 .219 .000 & $111,7 \%$ \\
\hline 2016 & 63.159 & 4.200 .000 .000 & 4.494 .070 .600 & $107 \%$ \\
\hline 2017 & 54.612 & 3.194880 .000 & 3.313 .235 .000 & $103,7 \%$ \\
\hline 2018 & 50.965 & 2.869 .515 .000 & 3.093 .985 .000 & $107,8 \%$
\end{tabular}

Sumber :data diolah (2019)

Berdasarkan tabel 1.1 dapat dilihat bahwa selama 4 tahun terakhir dari tahun 20152018 pencapaian target retribusi pengujian kendaraan di kota Denpasar selalu mencapai target yang ditetapkan ,namun setiap tahun target retribusi selalu mengalami penurunan disertai juga penurunan jumlah kendaraan, meskipun realisasi selalu melebihi dari target yang ditetapkan. fenomena lain yang terjadi yaitu persentase terjadinya fluktuasi pencapaian target yang tidak stabil setiap tahunnya. Tahun 2016 persentase pencapaian target mencapai $107 \%$ namun mengalami penurunan dari pencapaian realisasi di tahun 2015 yaitu $111,7 \%$ dan di tahun 2017 juga mengalami penurunan kembali menjadi 103,7 $\%$. Tahun 2018 persentase target menunjukkan peningkatan dari tahun sebelumnya yaitu pencapaian retribusi sebesar $107,8 \%$. Terjadinya fluktuasi persentase naik dan turun pencapaian realisasi retribusi pengujian kendaraan ini menjadi salah satu kendala terjadinya penurunan target PAD dan disisi lain dibarengi juga dengan berkurangnya jumlah kendaraan wajib uji di wilayah Kota Denpasar dari tahun 2015-2018. Disisi lain, penerimaan sektor retribusi daerah ini diharapkan dapat mendukung sumber pembiayaan 
daerah dalam menyelenggarakan pembangunan daerah yang akan dapat meningkatkan dan memeratakan perekonomian serta kesejahteraan masyarakat di daerah.

Upaya peningkatan PAD dapat dilakukan salah satunya dengan meningkatkan efisiensi sumber daya dan sarana yang terbatas serta meningkatkan efektifitas pemungutan. Retribusi daerah yang merupakan pembayaran atas jasa atau pemberian ijin khusus yang disediakan dan/atau diberikan oleh Pemda kepada pribadi/badan, diharapkan dapat mendukung sumber pembiayaan daerah dalam menyelenggarakan pembangunan daerah, sehingga akan meningkatkan dan memeratakan perekonomian serta kesejahteraan masyarakat di daerahnya. Berdasarkan latar belakang fenomena yang ada ,penulis tertarik untuk menyusun sebuah artikel terkait "Analisis Efektivitas Pelaksanaan Pemungutan Retribusi Kendaraan Bermotor Di Kota Denpasar".

Tujuan dari penelitian ini adalah untuk mengetahui efektivitas pelaksanaan pemungutan retribusi pengujian kendaraan bermotor di Kota Denpasar. Menurut Siagian (2007:24) efektivitas adalah pemanfaatan sumber daya, sarana dan prasarana dalam jumlah tertentu yang secara sadar ditetapkan sebelumnya untuk menghasilkan sejumlah barang atas jasa kegiatan yang dijalankan. Efektivitas menunjukkan keberhasilan dari segi tercapai tidaknya sasaran yang telah ditetapkan. Menurut Pasolong (2007:4) efektivitas pada dasarnya berasal dari kata "efek" dan digunakan istilah ini sebagai hubungan sebab akibat. Efektivitas dapat dipandang sebagai suatu sebab dari variabel lain. Efektivitas berarti bahwa tujuan yang telah direncanakan sebelumnya dapat tercapai atau dengan kata sasaran tercapai karena adanya proses kegiatan. Menurut Mahmudi (2005:92) efektivitas merupakan hubungan antara output dengan tujuan, semakin besar kontribusi (sumbangan) output terhadap pencapaian tujuan, maka semakin efektif organisasi, program atau kegiatan. Ditinjau dari segi pengertian efektivitas usaha tersebut, maka dapat diartikan 
bahwa efektivitas adalah sejauhmana dapat mencapai tujuan pada waktu yang tepat dalam pelaksanaan tugas pokok, kualitas produk yang dihasilkan dan perkembangan. Pendapat lain juga dinyatakan oleh Susanto, yaitu: "efektivitas merupakan daya pesan untuk mempengaruhi atau tingkat kemampuan pesan-pesan untuk mempengaruhi” (Winardi, 2007:156). Berdasarkan definisi tersebut, peneliti beranggapan bahwa efektivitas bisa tercipta jika pesan yang disampaikan dapat mempengaruhi khalayak yang diterpanya.

Adapun menurut pendapat Cambell yang dikutip oleh Richard M. Steers dalam bukunya Efektivitas Organisasi menyebutkan beberapa ukuran daripada efektivitas, yaitu:

a. Kualitas artinya kualitas yang dihasilkan oleh organisasi;

b. Produktivitas artinya kuantitas dari jasa yang dihasilkan;

c. Kesiagaan yaitu penilaian menyeluruh sehubungan dengan kemungkinan dalam hal penyelesaian suatu tugas khusus dengan baik;

d. Efisiensi merupakan perbandingan beberapa aspek prestasi terhadap biaya untuk menghasilkan prestasi tersebut;

e. Penghasilan yaitu jumlah sumber daya yang masih tersisa setelah semua biaya dan kewajiban dipenuhi;

f. Pertumbuhan adalah suatu perbandingan mengenai eksistensi sekarang dan masa lalunya;

g. Stabilitas yaitu pemeliharaan struktur, fungsi dan sumber daya sepanjang waktu;

h. Kecelakaan yaitu frekuensi dalam hal perbaikan yang berakibat pada kerugian waktu;

i. Semangat kerja yaitu adanya perasaan terikat dalam hal pencapaian tujuan, yang melibatkan usaha tambahan, kebersamaan tujuan dan perasaan memiliki; 
j. Motivasi artinya adanya kekuatan yang muncul dari setiap individu untuk mencapai tujuan;

k. Kepaduan yaitu fakta bahwa para anggota organisasi saling menyukai satu sama lain, artinya bekerja sama dengan baik,berkomunikasi dan mengkoordinasikan;

1. Keluwesan Adaptasi artinya adanya suatu rangsangan baru untuk mengubah prosedur standar operasinya, yang bertujuan untuk mencegah keterbekuan terhadap rangsangan lingkungan (Wibawa, 2003:46-48).

Berdasarkan penjelasan hal-hal yang dikemukakan di atas, maka ukuran efektivitas merupakan suatu standar akan terpenuhinya mengenai sasaran dan tujuan yang akan dicapai. Selain itu, menunjukan pada tingkat sejauh mana organisasi, program/kegiatan melaksanakan fungsi-fungsinya secara optimal. Efektivitas adalah tingkat pencapaian hasil program dengan target yang diterapkan dan secara sederhana efektivitas merupakan perbandingan antara Outcome dan Output (Mardiasmo, 2009:3). Rasio efektivitas menggambarkan kemampuan pemerintah daerah dalam merealisasikan pendapatan asli daerah yang direncanakan, dibandingkan dengan target yang ditetapkan berdasarkan potensi riil daerah dan dinyatakan dalam persentase (Halim, 2007:234).

Efektivitas adalah keberhasilan atau kegagalan dari organisasi dalam mencapai tujuannya. Menurut Halim (2007:235) efektivitas retribusi daerah menunjukkan kemampuan pemerintah daerah dalam mengumpulkan retribusi daerah sesuai dengan jumlah penerimaan retribusi yang ditargetkan. Maka efektivitas yang dimaksud adalah seberapa besar realisasi penerimaan retribusi daerah berhasil mencapai target yang seharusnya dicapai pada suatu periode tertentu dengan rumus sebagai berikut: 


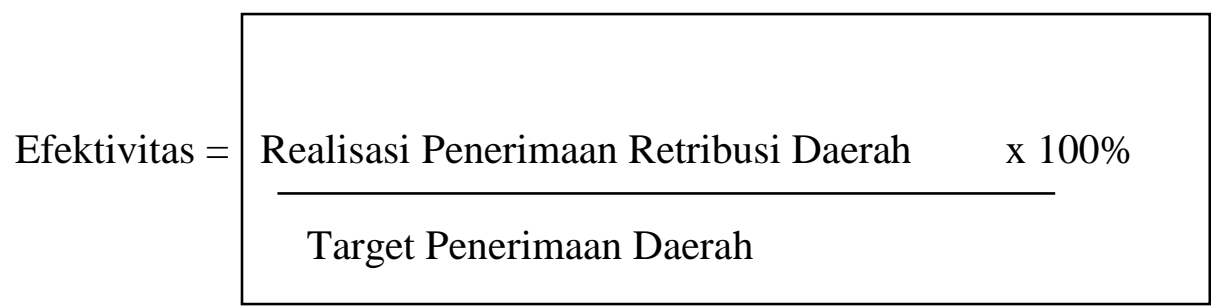

\section{Sumber: (Nick Devas dalam Rahmawati(2012:32)}

Semakin besar nilai efektivitas berarti semakin tinggi efektivitas penerimaan retribusi kendaraan daerah di Kota Denpasar. Untuk mengukur tingkat keberhasilan efektivitas penerimaan retribusi daerah di Kota Denpasar dapat juga dengan memberikan peringkat atau nilai hasil akhir, dengan menggunakan skala peringkat menurut Mahmudi (2007). Skala peringkat yang digunakan adalah :

a) Hasil perbandingan tingkat pencapaian diatas $100 \%$ berarti sangat efektif.

b) Hasil perbandingan tingkat pencapaian sama dengan $100 \%$ berarti efektif.

c) Hasil perbandingan tingkat pencapaian dibawah $100 \%$ berarti tidak efektif.

Dengan skala peringkat ini dapat juga kita gunakan untuk mengukur tingkat efektivitas dari penerimaan retribusi daerah lainnya yang ada di Kota Denpasar. Berdasarkan beberapa teori yang dikemukakan oleh para pakar diatas mengenai efektivitas, penulis menggunakan teori yang dikemukakan oleh Nick Devas dalam Rahmawati (2012:32). Hipotesis adalah jawaban yang bersifat sementara terhadap permasalahan peneliti melalui data yang terkumpul. Hipotesis dalam penelitian ini diduga pelaksanaan pemungutan retribusi Pengujian Kendaraan Bermotor di Kota Denpasar sangat efektif.

\section{METODE PENELITIAN}

Pemilihan informasi sebagai sumber data atau informan dalam penelitian ini berdasarkan asas subyek yang menguasai permasalahan dan masih terikat aktif, memiliki data dan bersedia memberikan informasi yang lengkap dan akurat, serta subjek mempunyai 
cukup waktu untuk diwawancara. Informan yang bertindak sebagai sumber data dan informasi harus memenuhi kriteria tersebut. Kriteria memilih informan sebagai narasumber (key informan) dalam penelitian ini adalah sebagai berikut:

\section{Tabel 3.1 Informan Penelitian}

\begin{tabular}{|c|c|c|c|c|}
\hline No & Informan & Jumlah sampel & $\begin{array}{l}\text { Tingkat } \\
\text { pendidikan }\end{array}$ & Jenis kelamin \\
\hline 1 & $\begin{array}{l}\text { Ka.UPT } \\
\text { Pengujian } \\
\text { Kendaraan Kota } \\
\text { Denpasar }\end{array}$ & 1 Orang & Sarjana (S1) & Laki-Laki \\
\hline 2 & $\begin{array}{l}\text { KasubagTU } \\
\text { UPT PKB }\end{array}$ & 1 Orang & Sarjana (S1) & Laki-Laki \\
\hline 3 & $\begin{array}{l}\text { Bendahara } \\
\text { Penerimaan } \\
\text { Retribusi UPT } \\
\text { PKB }\end{array}$ & 1 Orang & Sarjana (S1) & Perempuan \\
\hline 4 & $\begin{array}{l}\text { Penguji } \\
\text { Kendaraan UPT } \\
\text { PKB }\end{array}$ & 17 Orang & $\begin{array}{l}\text { Sarjana: } 2 \text { org } \\
\text { D2: } 15 \text { org }\end{array}$ & $\begin{array}{l}\text { Laki-laki: } 15 \\
\text { Perempuan : } 2\end{array}$ \\
\hline 5 & $\begin{array}{l}\text { Pegawai } \\
\text { Administrasi } \\
\text { UPT PKB }\end{array}$ & 25 Orang & $\begin{array}{lr}\text { Sarjana }: 11 \text { org } \\
\text { D3: } \quad 2 \text { org } \\
\text { SMA : } & 12 \text { org }\end{array}$ & $\begin{array}{l}\text { Laki-laki: } 19 \\
\text { Perempuan: } 6\end{array}$ \\
\hline
\end{tabular}

Sumber : data diolah (2019)

Setelah dalam proses pengumpulan data tidak lagi ditemukan variasi informasi, maka peneliti tidak mencari informasi baru, proses pengumpulan informasi dianggap selesai. Dengan demikian penelitian kualitatif tidak dipersoalkan jumlah informan, tetapi juga bisa tergantung dari tepat tidaknya pemilihan informan kunci, dan kompleksitas dari keragaman fenomena sosial yang diteliti.

Jenis data pada penelitian ini adalah data kualitatif dan data kuantitatif.

a. Data kuantitatif, yaitu data-data berbentuk angka yang diperoleh dari dinas instansi terkait yang berkaitan dengan data Target Pendapatan Asli Daerah (PAD) dari sumber retribusi Pengujian kendaraan bermotor di Kota Denpasar.

b.Data kualitatif, yaitu uraian-uraian kalimat yang diperoleh berupa informasi 
penelitian melalui kegiatan wawancara dengan responden penelitian terpilih. Wawancara adalah proses memperoleh keterangan untuk tujuan penelitian dengan tanya jawab sambil bertatap muka antara pewawancara dan informan dengan menggunakan alat yang dinamakan interview guide (panduan wawancara) (Nazir,1999).

Sumber data penelitian ini dibedakan atas:

a. Data Primer adalah data yang penulis peroleh dari hasil penelitian langsung dari tanggapan responden melalui wawancara pada responden terkait masalah yang diberikan mengenai Efektivitas pelaksanaan pemungutan retribusi Pengujian Kendaraan Kota Denpasar.

b. Data Sekunder adalah data yang penulis peroleh dalam bentuk data yang sudah tersedia yang diperoleh pada kantor UPT.Pengujian Kendaraan Bermotor Kota Denpasar.

\section{HASIL DAN PEMBAHASAN}

Berdasarkan perhitungan kontribusi pendapatan retribusi Pengujian kendaraan bermotor di tahun 2015 sampai dengan tahun 2018 di wilayah Kota Denpasar dapat diketahui kontribusi pendapatan Retribusi Pengujian Kendaraan di Kota Denpasar adalah sesuai pada tabel berikut ini

Tabel 4.1

Rekapitulasi Tingkat Pertumbuhan serta Efektivitas

Retribusi Pengujian Kendaraan Bermotor di Kota Denpasar

Tahun 2015 s.d. 2018

\begin{tabular}{llll} 
Tahun & Persentase & Efektivitas & Keterangan \\
\hline 2015 & $111,7 \%$ & Sangat efektif & - \\
\hline 2016 & $107 \%$ & Sangat efektif & Turun \\
\hline 2017 & $103,7 \%$ & Sangat efektif & Turun \\
\hline
\end{tabular}


Widya Akuntansi dan Keuangan

Universitas Hindu Indonesia

Edisi Agustus 2019, ISSN 2655-9498

2018

$107,8 \%$

Sangat efektif

Naik

\begin{tabular}{lll}
\hline Rata-Rata & $\mathbf{1 0 7 , 5} \%$ & Sangat Efektif
\end{tabular}

Dari hasil penelitian yang diperoleh, menunjukkan pertumbuhan Retribusi Pengujian Kendaraan terus mengalami penurunan dari tahun 2016 dan 2017 dan mengalami kenaikan di tahun 2018 meskipun efektivitasnya menunjukkan sangat efektif. Dari hasil penelitian yang diperoleh juga dapat menunjukkan keefektivitasan dari Pemerintah Daerah Kota Denpasar dalam mengoptimalkan dan mengevaluasi sumber Pendapatan Asli Daerah (PAD) khususnya dari penerimaan Retribusi Pengujian Kendaraan Bermotor. Hal ini dapat dilihat dari rata-rata persentase pencapaian target realisasi yaitu $107,5 \%$ yang menunjukkan sangat efektif. Hasil penerimaan yang bersumber dari penerimaan Retribusi Pengujian Kendaraan Bermotor dari tahun 2015 sampai dengan tahun 2018 yang mengalami Pencapaian Target Retribusi yang sangat efektif yaitu persentase pencapaian lebih dari seratus persen dari tahun 2015 sampai 2018. Pada tahun 2018 persentase keefektivan mencapai 107,8 \% Ini menunjukkan tahun 2018 kinerja untuk realisasi penerimaan Retribusi Pengujian Kendaraan sudah mulai menunjukkan kinerja yang optimal.

Pencapaian penerimaan target PAD Retribusi Pengujian Kendaraan di Kota Denpasar yang sangat efektif ini merupakan peningkatan hal yang dikarenakan pemerintah daerah kota Denpasar mengarahkan sumber daya tenaga pemungut retribusi,staf penguji dan administrasi kantor yang bekerja sangat maksimal dalam melaksanakan pengujian kendaraan dan melayani masyarakat dengan moto Denpasar yaitu "sewaka dharma" yang artinya melayani adalah kewajiban, serta menghimbau pada warga wajib uji pemilik kendaraan agar melakukan uji pada kendaraannya agar laik jalan dan tepat pada waktunya.

\section{KESIMPULAN}

Sesuai dengan tujuan penelitian yaitu untuk mengetahui bagaimana efektivitas pelaksanaan pemungutan retribusi pengujian kendaraan bermotor di Kota Denpasar, 
efektivitas retribusi pengujian kendaraan selama periode tahun 2015 sampai dengan tahun 2018 mencapai rata-rata $107,5 \%$ yang berarti sangat efektif. Hal ini berarti pemungutan retribusi pengujian kendaraan di Pemerintah Daerah Kota Denpasar sudah sangat efektif karena hasil perbandingan tingkat pencapaian diatas $100 \%$ yang berarti sesuai dengan ukuran efisiensi efektivitas hasilnya adalah sangat efektif.

\section{SARAN}

Dari kesimpulan yang dikemukakan diatas maka berikut ini akan dikemukakan saransaran penulis sebagai berikut:

1. Pencapain sangat efektif dari tahun ke tahun meskipun mengalami kenaikan dan penurunan seharusnya pemerintah Kota Denpasar tidak menetapkan Target PAD pada pengujian karena masuk dan keluarnya kendaraan wajib uji di wilayah kota Denpasar tidak bisa kita prediksi setiap tahunnya.

2. Kepada pemerintah daerah Kota Denpasar agar lebih melengkapi sarana dan prasarana penunjang keefektivan yang ada agar masyarakat mau datang untuk melakukan uji KIR pada mobil yang dipersyaratkan wajib uji dan membayar retribusi atas jasa uji tersebut.

3. Penelitian yang akan datang perlu juga mempertimbangkan kontribusi pajak daerah dan retribusi daerah dari sektor lainnya misalnya hotel, restoran dan fasilitas parkir. untuk lebih meningkatkan Pendapatan Asli Daerah (PAD) di Kota Denpasar.

\section{DAFTAR PUSTAKA}

Badjuri Abdulkahar, Teguh Yuwono, 2003, Kebijakan Publik Konsep dan Strategi, FISIP UNDIP, Semarang.

Jufaizal. 2016. Analisis Efektifitas Pelaksanaan Pemungutan Retribusi Sampah Kabupaten Rokan Hulu. Jurnal.Universitas Pasir Pangairan. 
Husseini, Martini dan Lubis, 2011, Teori Organisasi (Suatu Pendekatan Makro), Pusat Antar Universitas Ilmu-ilmu Sosial Universitas Indonesia.

Halim. Abdul (2007). Akuntansi Sektor Publik Akuntansi Keuangan Daerah, Edisi Revisi, Jakarta, Salemba Empat.

Kurniawan Agung. 2005. Transformasi Pelayanan Publik. Yogyakarta: Pembaruan.

Mahmudi. 2007. Manajemen Kinerja Sektor Publik. Yogyakarta : UPP STIM YKPN.

Mardiasmo, 2009. Akuntansi Sektor Publik. ANDI: Yogyakarta.

Mahmudi, 2005, Manajemen Kinerja Sektor Publik, Yogyakarta : Akademi Manajemen Perusahaan YKPN.

Moh, Nazir . 1999, Metode Penelitian, Cetakan Ketiga, Jakarta, Ghalia Indonesia.

Peraturan Daerah Kota Denpasar Nomor $20 \quad$ Tahun 2011 Tentang Retribusi Pengujian Kendaraan Bermotor

Pasolong, Harbani. 2007. Teori Administrasi Publik. ALFABETA.

Rahmawati, Siti. 2012. Kontribusi Pajak Daerah Terhadap Pendapatan Asli Daerah (PAD) dan Anggaran Pendapatan dan Belanja Daerah (APBD) Kabupaten Grobogan Periode 2006-2010. Skripsi. Non Publikasi

Siagian, Sondang P. 2007. Manajemen Sumber Daya Manusia. Edisi Pertama, Cetakan keempatbelas, Penerbit ; Bumi Aksara. Jakarta.

Steers Richard. M.. 2005. Efektivitas Organisasi. (Terjemahan). Jakarta: Erlangga.

Thoha, Miftah. 2010, Kepemimpinan dan Manajemen, Devisi Buku Perguruan Tinggi, PT. Raja Grafindo Persada, Kakarta

Undang - Undang No.23 Tahun 2014, Tentang Pemerintah Daerah.

Wibawa, Samodra. 2006. Evaluasi Kebijakan Publik.Jakarta. PT Raja Grafindo Persada.

Winardi, J. 2007. Motivasi dan Pemotivasian Dalam Manajemen. Jakarta. PT Raja Grafindo Persada. 